\title{
Dakwah Berbasis Konten Lokal: Analisis Ceramah Adat Basandi Syarak, Syarak Basandi Kitabullah
}

\author{
Putra Chaniago \\ Magister Komunikasi Penyiaran Islam \\ Universitas Islam Negeri Sunan Kalijaga Yogyakarta
}

Korespodensi dengan Penulis:

Putra Chaniago: Telp: 082283432505

E-mail: putra.uinsuka2020@gmail.com

Keywords:

Lecture analysis,

Local da'wah,

Adat Basandi

Syarak, Syarak

Basandi

Kitabullah, Minangkabau.
Abstract

The main problem in this research is the analysis based on local content analysis on the video of the lectures traditional of adat basandi syarak, syarak basandi kitabullah by Ustadz Zulhamdi Lc, MA. Researchers want to know how a discourse is built in a culture-based da'wah conducted by religious scholars in Minangkabau. This type of research is qualitative descriptive, using documentation studies as a data collection technique. Then use the method of discourse analysis Teun van Dijk. The findings of the study show that the customary lecture of adat basandi syarak, syarak basandi kitabullah by Ustadz Zulhamdi Lc, MA is seen from the aspect of social analysis, text and social cognition, namely building a religious discourse, amar ma'ruf nahi mungkar. Departing from the concerns of the scholars in an effort to maintain the Islamic tradition and strengthen the character of the Minangkabau people known as the state of the scholars, amid the issues of moral and mental damage to Minangkabau youth today. Local content-based da'wah through a long-believed philosophy of life, becomes a solution to return to the order of life in accordance with the expectations of the ancients who lived in a strong religious tradition fortifying themselves and generations of mental and moral decline. Da'wah is a flexible and universal activity, so with local content-based da'wah can be a solution to the problems that occur in the community under its auspices.

\section{Abstrak}

Pokok permasalahan dalam penelitian ini adalah dakwah berbasis konten lokal, anilisis terhadap video ceramah adat basandi syarak, syarak basandi kitabullah oleh Ustadz Zulhamdi Lc, MA. Peneliti ingin mengetahui bagaimana sebuah wacana dibangun dalam dakwah berbasis budaya yang dilakukan oleh alim ulama di Minangkabau. Jenis penelitian ini yaitu deskriptif kualitatif, menggunakan studi dokumentasi sebagai Teknik pengumpulan data. Kemudian menggunakan metode analisis wacana Teun van Dijk. Temuan penelitian menunjukkan bahwa ceramah adat basandi syarak, syarak basandi kitabullah oleh Ustadz Zulhamdi Lc, 
MA dilihat dari aspek analisis sosial, teks dan kognisi sosial, yaitu membangun suatu wacana keagamaan, amar ma'ruf nahi mungkar. Berangkat dari kerisauan para ulama tersebut berupaya mempertahankan tradisi keislaman dan memperkokoh karakter masyarakat Minangkabau yang dikenal sebagai negerinya para ulama, ditengah isu kerusakan moral dan mental pemuda Minangkabau saat ini. Dakwah berbasis konten lokal melalui falsafah hidup yang telah lama diyakini, menjadi solusi untuk kembali kepada tatanan kehidupan yang sesuai dengan harapan para leluhur dahulu yang hidup dalam tradisi keagamaan yang kokoh membentengi diri dan generasi dari kemerosotan mental dan akhlak. Dakwah adalah aktivitas yang fleksibel dan universal, sehingga dengan dakwah berbasis konten lokal bisa menjadi solusi terhadap persoalan yang terjadi dalam masyarakat yang dinaunginya.

\section{PENDAHULUAN}

Agama dan budaya menjadi unsur penting dan berkontribusi dalam bangunan karakter suatu daerah. Nietzsche mengatakan bahwa Kebudayaan sebagai insting natural ke arah pemekaran diri secara optimal yang tidak semata berasal dari imajinasi kreatif, melainkan tumbuh dari daya kehidupan sehari-hari. ${ }^{1}$ Menurut Koentjaraningrat, kebudayaan adalah seluruh sistem gagasan, tindakan dan hasil karya manusia dalam kehidupan bermasyarakat yang dijadikan milik diri manusia dengan belajar. ${ }^{2}$ Oleh karena itu, untuk mengetahui karakteristik suatu daerah dapat dilakukan melalui pendekatan agama dan budaya masyarakat setempat. ${ }^{3}$

Minangkabau merupakan bagian dari keunikan alam Indonesia. Daerah ini dikenal dengan budaya yang khas, unik serta mengandung banyak nilai-nilai filosofis. Suku Minangkabau dekat dengan alam, karena wilayahnya yang agraris, dengan adanya gunung marapi dan gunung singgalang yang menjadi awal persebaran suku ini. Minangkabau kemudian menjadi suku asli dari Wilayah Provinsi Sumatera Barat. Keunikan lain dari Minangkabau adalah terkenal sebagai suku yang suka merantau. Merantau atau menyebar ke seluruh negeri di luar negerinya sendiri. Perseberan mereka sampai ke wilayah Jiran di Negeri Sembilan, Malaysia bahkan terdapat sebuah kerajaan sendiri dengan adat parpatih di Seremban, Malaysia dan mengikuti sistim matrilineal seperti halnya yang dianut suku Minangkabau.

Menurut Buya Hamka, ada dua Aspek penting yang menjadi rujukan di Minangkabau, yaitu aspek agama dan aspek adat. ${ }^{4}$ Aspek agama mengalami regenerasi yang panjang dan terus

${ }^{1}$ F. Simon, Kebudayaan dan Waktu Senggang (Yogyakarta: Jalasutra, 2006) hlm.19

2 Koentjaraningrat, Pengantar Ilmu Antropologi (Jakarta: Rineka Cipta, 2009) hlm. 144

${ }^{3}$ Rachmat Afandi, Makna Filosofis dalam pepatah Minangkabau Adat Basandi Syara' syara' basandi Kitabullah : analisis semiotika Ferdinan De Saussure, (Yogyakarta, Fakultas Dakwah UIN Sunan kalijaga, 2017) hlm. 1

${ }^{4}$ Hamka, Islam dan Adat Minangkabau (Jakarta: Pustaka Panjimas, 1984) hlm. 10 
mengalami ketersinambungan. Dimulai dari perkembangan agama Budha yang dibawa oleh Raja Adityawarman yang merupakan pecahan dari kerajaan sriwijaya, melakukan ekspansi ke wilayah Minangkabau dan menetapnya Adityawarman sebagai Maharaja. Pemahaman inilah yang kemudian berkembang menjadi kepercayaan masyarakat dan dalam jangka panjang menjadi agama pertama yang dianut masyarakat Minangkabau. Hal tersebut dibuktikan dengan adanya benda-benda bersejarah, bukti arkeologis, dan penemuan-penemuan lainnya, serta dari penggunaan nama-nama daerah seperti saruaso, Padang Bahalo, Pariangan dan daerah lainnya yang diketahui berasal dari penyebutan dalam tradisi hindu. ${ }^{5}$

Menurut Buya Mas'ud abidin, seorang ulama terkemuka di Sumatera Barat, Minangkabau memiliki tatanan kehidupan masyarakat yang sangat ideal. Minangkabau menetapkan bahwa landasan dan tatanan kehidupan masyarakat adalah nilai-nilai, norma-norma adat dan agama islam yang menyeluruh dalam satu ungkapan yang berbunyi "Adat Basandi Syarak, Syarak Basandi Kitabullah." Adat dan syarak merupakan benteng kehidupan di dunia dan di akhirat. Istilah ini lahir dari sebuah peristiwa di Bukit Marapalam, di daerah Batusangkar, Kabupaten tanah datar sekarang. Peristiwa bersejarah tersebut terjadi pada awal abad ke 19. Dengan adanya suatu perundingan antara kaum adat dan kaum ulama di Minangkabau. Perundingan tersebut menghasilkan sebuah konsensus yang dikenal dengan Piagam Sumpah Satie Bukik Marapalam. Kemudian diyakini masyarakat sebagai awal bersatunya nilai-nilai adat didasari dengan nilainilai Islam yang sesuai dengan Al Qur'an dan sunnah, sekaligus menjadi konsep "Pandangan Dunia dan Pandangan Hidup (PDPH)" serta inti Adat Minangkabau. ${ }^{6}$

Sebuah realitas di ranah Minangkabau bahwa adat basandi Syarak, syarak basandi kitabullah dari dulu telah menjadi landasan hidup masyarakat Minangkabau sebagai tataran yang ideal. Namun hal tersebut mulai terkikis oleh faham yang datang dari luar. Perang pemikiran (Ghozul Fikri) juga menyentuh aspek budaya dan akhlak pemuda Minang. Berkembangnya faham liberalisme, modernisme, hedonisme, dan pesatnya arus globalisasi ditengah masyarakat di Minangkabau menjadi suatu perdebatan yang tak hentinya dilakukan. Bahkan pernah dinyatakan bahwa Sumatera Barat tertinggi dalam perceraian7, LGBT ${ }^{8}$ dan Narkoba. Hal ini

${ }^{5}$ Cristine Dobbin, Gejolak Ekonomi, Kebangkitan Islam dan Gerakan Paderi Minangkabau (Depok: Komunitas Bambu, 2008) hlm. 204

${ }^{6}$ H. Mas'oed Abidin, Tiga Sepilin: Suluah Bendang Dalam Nagari. (Yogyakarta:Gre Publishing, 2016) hlm. 11

7 Tisna, S. Pd, “Tingginya Angka Perceraian Di Sumatera Barat," Metro Padang, 7 September 2020 https://www.metropadang.com/tingginya-angka-perceraian-di-sumatera-barat/

8Rizka Yesri Yusfita, "Populasi LGBT Terbanyak ada di Sumatera Barat, Penyebabnya salah satunya keluarga," Wota Live.com, 7 Mei 2019 https:// wartakota.tribunnews.com/2019/05/07/populasi-lgbt-terbanyak-ada-di-sumatera-baratpenyebabnya-salah-satunya-karena-keluarga 
kemudian melatari para alim ulama melakukan sebuah gerakan supremasi terhadap falsafah hidup Minangkabau tersebut.

Perjalanan serah terima generasi Minangkabau, berbagai fenomena yang mencemaskan, bila tidak diatasi akan menjadi buah ratapan di masa yang akan datang. Perlu adanya upaya edukasi dan persuasi kepada masyarakat, terutama dikalangaan millenial untuk membendung datangnya pemahaman membahayakan serta rusaknya akhlak generasi penerus di Sumatera Barat. ${ }^{9}$ Munculnya upaya supremasi terhadap falsafah hidup Minangkabau tersebut melalui gerakan dakwah para ulama di Minangkabau. Salah satu tokoh ulama di Sumatera Barat yang terus berupaya mempertahankan nilai-nilai adat berlandaskan agama Islam tersebut yaitu Ustadz Zulhamdi Malin Mudo, Lc. MA. Saat ini pria yang biasa dipanggil Buya Zulhamdi Malin Mudo ini menjabat sebagai ketua MUI Kota Padang Panjang periode 2016-2020. Gerakan dakwah dilakukan dengan metode ceramah yang berisi pesan-pesan budaya tradisional dalam pengajiannya di surau-surau di Minangkabau. Dari bentuk pesan yang disampaikan, pesanpesan dalam ceramahnya membangun wacana di masyarakat untuk kembali kepada tataran nilai, landasan hidup yang berdasarkan falsafah adat basandi syarak, syarak basandi kitabullah. Sealin itu Ustadz Zulhamdi Lc, MA berceramah dengan retorika yang baik dengan kato pusako, seperti pantun adat dan petatah petitih Minangkabau yang membuat ceramah agamanya terdengar unik dan menarik.

Dakwah adalah akivitas yang dinamis, fleksibel dan bersifat universal. Dakwah akan selalu mengalami perkembangan seiring dengan terjadinya pembaruan dan modernisasi. Dakwah dalam level makro memiliki peran besar dalam menciptakan kehidupan yang harmonis, terkendalinya situasi yang aman dan kondusif ditingkat global atau secara menyeluruh. Sedangkan di level mikro, dakwah memiliki peran dalam mengendalikan kehidupan masyarakat kepada tataran kehidupan yang harmonis dan kondusif berpijak pada kepentingan-kepentingan dan kearifan budaya lokal. Dengan demikian, dakwah yang berbasis budaya penting dilakukan sebagai upaya mempertahankan tradisi lokal sekaligus menjaga tataran kehidupan di masyarakat dan tradisi pada suatu daerah.

Oleh karena itu, penulis tertarik melakukan penelitian analisis wacana kritis dalam sebuah ceramah agama. Peneliti berusaha membongkar bagaimana wacana yang dibangun oleh Ustadz Zulhamdi Lc, MA pada ceramah adat basandi syarak, syarak basandi Kitabullah (ABSSBK). Penelitian ini penting dilakukan sebagai upaya memperdalam metode dakwah dengan pendekatan konten budaya lokal dengan wacana keagamaan untuk menjawab persoalan di tengah masyarakat. Objek penelitian yaitu sebuah video ceramah Ustadz Zulhamdi Lc, MA yang penulis unduh dari

9 Putra Chaniago, "Representasi Pendidikan Karakter dalam Film Surau dan Silek (Analisis Semiotika Ferdinand De Saussure)" Journal Islamic Education Policy, Vol. 4. No. 2, 2019, hlm. 137. 
Youtube. Video tersebut kemudian dianalisis dengan menggunakan teori analsisis wacana kritis Teun Van Dijk. Teori Van Dijk dirasa sesuai dengan kebutuhan dalam penelitian analisis ini, dimana ia menggambarkan wacana dalam tiga dimensi yaitu teks, kognisi sosial dan konteks sosial. ${ }^{10}$ Tujuan penulis mengangkat penelitian ini adalah untuk mengetahui bagaimana isi pesan dakwah, ideologi dan pemikiran Ustadz Zulhamdi Lc, MA dalam menyiarkan Islam di Minangkabau. Penulis juga ingin mengetahui bagaimana makna adat basandi syarak, syarak basandi Kitabullah yang sebenarnya.

Adapun beberapa karya tulis ilmiah yang dapat penulis jadikan sebagai rujukan termuat dalam bentuk jurnal, buku, dan skripsi yaitu diantaranya ; Skripsi oleh Rahmad Afandi11. Fokus skripsi Rahmad Afandi ini yaitu lebih menitik beratkan pada pertalian makna dari hubungan antara adat dan agama dalam unsur filosofis. Aspek Bahasa dipengaruhi oleh sosio-historis sesuai dengan linguistik-historis yang di kembangkan oleh Ferdinand De Saussure. Adapun aspek sejarah yang mempengaruhi tak terlepas dari perpaduan antara unsur adat dan agama yang lahir dari sejarah yang telah dilukiskan.

Selain itu juga terdapat penelitian yang dilakukan oleh Ahmad Sarbini. ${ }^{12}$ Perbedaan mendasar dengan penelitian yang penulis lakukan adalah terletak pada fokus penelitian, serta metode penelitian yang digunakan. Fokus penelitiannya adalah menemukan realitas budaya masyarakat di jawa barat, adanya relasi dakwah dan budaya lokal di jawa barat, serta terdapat model dakwah budaya di Jawa Barat. Sedangkan dalam penelitian ini, berupaya menemukan bagaimana wacana yang dibangun dalam ceramah yang menggunakan konten budaya lokal dalam menjawab persoalan yang ada ditengah masyarakat.

\section{METODE}

Jenis penelitian ini adalah deskriptif kualitatif. Penelitian ini akan membahas tentang dakwah berbasis budaya lokal Minangkabau, analisis ceramah Adat basandi syarak, syarak basandi kitabullah oleh Ustadz Zulhamdi Lc, MA di youtube. Sumber data primer dalam penelitian ini yang kemudian akan menjadi objek penelitian adalah sebuah video ceramah Ustadz Zulhamdi Lc, MA yang di unduh dari Youtube. Satu video tersebut dirasa cukup untuk menjadi bahan analisis ceramah berbasis budaya Minangkabau oleh Ustadz Zulhamdi, Lc, MA. Video tersebut berjudul “Ustadz Zulhamdi Lc, MA (ceramah ABSSBK)” dengan durasi 1 jam, 12 menit, 10 detik.

${ }^{10}$ Eriyanto, Analisis Wacana: Pengantar Analisis Teks Media, (Yogyakarta: PT LKis Printing cermerlang, 2011) hlm. 275

${ }_{11}$ Rahmad Afandi, "Makna Filosofis Dalam Pepatah Minangkabau Adat Basandi Syarak Syarak Basandi Kitabullah". Skripsi, (Yogyakarta: UIN Sunan Kalijaga, 2017)

${ }^{12}$ Ahmad Sarbini, “Model Dakwah Berbasis Budaya Lokal Di Jawa Barat”, Jurnal Ilmu Dakwah, (Vol. 5 No. 17 Januari-Juni 2011) hlm. 292-322 
Adapun link video ceramah tersebut dilampirkan yaitu https://www.youtube.com/watch?v=sA6vDnzz94E yang diakses pada 28 Desember 2020 sudah ditonton sebanyak 23.296 kali.

Teknik pengumpulan data yaitu dengan studi dokumentasi. Dimana peneliti meniliti sebuah video ceramah yang diunduh dari dari Youtube. Sedangkan Teknik analisis data dalam penelitian ini adalah yaitu menggunakan teori miles dan haberman, yaitu diawali dengan reduksi data, penyajian data, serta menyampaikan dalam kesimpulan dan verifikasi.

Untuk menganalisis isi ceramahnya, penulis menggunakan teori Analisis wacana oleh Teun A. Van Dijk dengan menggunakan video ceramah Ustadz Zulhamdi Lc. MA tentang adat Basandi Syarak syarak Basandi Kitabullah di youtube dalam penelitian ini dilakukan dengan cara menginterpretasi dan menafsirkan teks-teks yang ada sehingga subyektifitas tidak dapat dihindari. Namun meminimalkan subyektifitas adalah cara yang dilakukan untuk memertahankan penelitian ini sebagai sebuah karya akademik. Model Van Dijk sering juga disebut sebagai "kognisi sosial" karena tidak terlepas dari karakteristik pendekatan yang ia perkenalkan. Menurut Van Dijk penelitian terhadap wacana tidak cukup hanya didasarkan pada analisis teks semata, karena teks hanya hasil dari suatu praktik produksi yang harus juga diamati.

Di sini harus dilihat juga bagaimana suatu teks diproduksi sehingga kita memperoleh suatu pengetahuan kenapa bisa semacam itu. Dalam produksi sebuah ceramah yang disampaikan oleh seorang Da'i, kita juga melihat konteks sosial masyarakat atau mad'u-nya. Penelitian mengenai wacana tidak bisa mengekslusi seakan-akan teks adalah bidang yang kosong, sebaliknya ia adalah bagian kecil dari struktur besar masyarakat. Pendekatan yang dikenal engan kognisi sosial ini membantu memetakan bagaimana produksi teks melibatkan proses kompleks tersebut dapat dipelajari dan dijelaskan. ${ }^{13}$

\section{HASIL DAN PEMBAHASAN}

\section{Analisis Sosial}

Analisis sosial melihat bagaimana suatu teks diproduksi atau dalam hal ini pesan ceramah yang disampaikan oleh Ustadz Zulhamdi Lc, MA dihubungkan lebih jauh dengan dengan struktur sosial dan pengetahuan yang berkembang dalam masyarakat atas suatu wacana.

\section{Falsafah Hidup: Adat Basandi Syarak, Syarak Basandi Kitabullah}

Bersatunya antara agama dengan budaya lokal Minangkabau disebabkan oleh lahirnya gerakan nasionalisme pada 11 Januari 1883, ketika itu antara golongan agama dan golongan adat bersatu dalam pemberontakan melawan belawan Belanda. Tujuannya mengalahkan dan mengusir Belanda dari bumi Minangkabau. Hasil ini kemudian dikenal dalam kalimat adat

${ }^{13}$ Eriyanto, Analisis Wacana : Pengantar Analisis Teks Media..., hlm. 221-222 
basandi syarak syarak basandi kitabullah pada tahun 1921 yang bertempat di Puncak pato, Tabek Patah, Batusangkar. ${ }^{14}$ Perpaduan unsur adat dan agama menghasilkan makna yang terkandung dalam sebuah konsep Adat Basandi syarak-syarak basandi Kitabullah yang menjadi panutan setiap tindakan.

Sebagai dasar filosofi kehidupan dalam masyarakat Minangkabau pepatah Adat basandi syarak, syarak basandi kitabullah telah mengakar kuat dalam setiap masyarakat dan tidak heran jika setiap wilayah Minangkabau sistem adat menjadi terlengkapi dan menjadi kuat dengan adanya Islam. ${ }^{15}$ Adat basandi syara', syara' basandi kitabullah adalah landasan yang senantiasa menjaga kaum ini dalam kesehariannya. Sandi dalam bahasa minang berarti landasan pondasi, atau dasar. Seperti di Rumah gadang, tiang-tiang rumah gadang dilandasi oleh batu minyak yang datar dan keras. Batu-batu tersebut mampu menjadi penyeimbang, memperkokoh berdirinya tiang, dan menjaga agar tak lapuk di makan tanah. Sehingga keberadaan sandi di Rumah gadang tak dapat di pisahkan. Begitu lah adat dan syari'at islam. Jadi rumah di ibaratkan dengan adat, dan syari'at islam diibaratkan dengan sandi. Dalam masyarakat Minangkabau dua unsur ini menjadi suatu hal yang sangat sentral. Seperti yang dikatakan oleh Buya Hamka, jika ada adat Minangkabau yang lepas dari sendinya yaitu Kitabullah maka itu adalah adat jahiliyah. ${ }^{16}$ Oleh karena itu, adat akan dapat bertahan apabila berdiri pada sendinya yakni Islam.

Islam datang ke Minangkabau di abad ke tujuh, dan jauh sebelum itu Minangkabau sudah tersusun rapi dengan adat istiadatnya. Meskipun demikian tidak jarang juga di temui adanya konsep adat atau tradisi yang telah lama dimiliki namun tak sesuai dengan ajaran agama Islam. Namun inilah yang kemudian menjadi cikal bakal terjadinya persatuan antara agama dan adat yang kemudian dikenal sebagai falsafah adat yang berbunyi Adat Basandi Syara', Syara' Basandi Kitabullah. Konsep pandangan dunia dan pandangan hidup (PDPH) yang merupakan inti dari adat Minangkabau (adat nan sabana adat) mempengaruhi sikap dan tata cara pergaulan, yang lebih di kenal sebagai adat nan di adatkan dan adat nan teradat. Adat istiadat Minangkabau mengatur rambu-rambu dan pola sikap perilaku seluruh anggota masyarakatnya. Dalam pola ini juga diatur tatanan kehidupan yang bersumber dari ajaran Islam sebagai yang di anut oleh masyarakat Minangkabau. Maka, terdapat istilah orang minangkabau adalah orang yang beragama islam. Maka, itulah yang menuntut mereka agar senantiasa berbuat dengan dasar cerminan hidup yang di ajarkan oleh al-Qur'an.

14 Sebagian sumber juga menyebutkan bahwa bukti pertemuan antara golongan agama dan golongan adat bertempat di Batu Batikam pada akhir abad ke 19.. lihat Safwa Rozi, "Negosiasi Islam Kultur Dalam Gerakan Paderi Rao Di Sumatera Tengah 1821-1833", Kalam : Jurnal Studi Agama dan Pemikiran Islam, Vol. 6, No. 1, Juni, 2012, hlm. 87

${ }^{15} \mathrm{Ibid}, . . \mathrm{hlm} .87-88$

${ }^{16}$ Hamka, Islam dan Adat Minangkabau (Jakarta: Pustaka Panjimas, 1984) hlm. iii 
Kedudukan Ulama di tengah masyarakat dikenal sebagai pemimpin yang menjadi panutan, pengayom dan pelindung di tengah masyarakatnya. Ulama adalah bagian dari tali tigo sapilin atau tungku tigo sajarangan satu kesatuan dari tiga unsur pemimpin umat di tengah masyarakat minangkabau yang terdiri dari ; ulama (mewakili kaum agama), ninik mamak (mewakili kaum adat), dan cadiak pandai (mewakili kaum cendikiawan). Seorang Ulama begitu di muliakan di Minangkabau. Kemuliaan seorang Murabbi pendidik umat dipancarkan dari keikhlasan membentuk anak manusia menjadi generasi pintar yang berilmu dan mengamalkan ilmunya. Membentuk generasi Minangkabau yang berbudi luhur atau ber-akhlakul karimahdalam bertindak dan berbuat untuk kebaikan.

Minangkabau menetapkan bahwa landasan dan tatanan kehidupan masyarakat adalah nilai-nilai, norma-norma adat dan agama islam yang menyeluruh dalam satu ungkapan yang berbunyi "Adat Basandi Syarak, Syarak Basandi Kitabullah." Adat dan syarak merupakan benteng kehidupan di dunia dan di akhirat. Dalam pepatah lainnya, menyatakan bahwa "kasudahan adaik ka balairung, kasudahan syarak ka akhiraik (titik akhir adat adalah ke balairung, titik akhir agama adalah ke akhirat)"

\section{Perang Paderi dan Manfaatnya Bagi Masyarakat Minangkabau}

Pada ceramah Ustadz Zulhamdi menjelaskan banyak manfaat perang paderi itu. Pertama, muncul istilah yang disepakati oleh daerah di Minangkabau, bahwa landasan mereka adalah adat basandi syarak, syarak basandi kitabullah, ini hasil pertama dari perang paderi. Hasil yang kedua, setelah perang paderi muncul semangat untuk menuntut ilmu yang tinggi di alam Minangkabau. Maka anak muda Minang, setelah perang paderi itu berduyun-duyun pergi ke Makkah, dan sekaligus membantah tuduhan kalau penyebab perang paderi itu karena pulangnya tiga haji dari Makkah. Kalaulah tiga haji pulang dari makkah penyebab pederi, sesudah perang paderi orang akan takut pergi ke Makkah. Buat apa pergi ke Makkah, nanti pulang dari Makkah membuat perang pula kerjanya. Namun yang terjadi adalah sebaliknya, sudah perang paderi orang tua masing-masing suku dikirimnya kemenakannya buat pergi ke makkah. Mereka ingin juga belajar, dimana haji Miskin dulu belajar, mereka disana juga ingin belajar. Dimana haji piobang menuntut ilmu, dia ingin juga kemenakannya disitu menuntut ilmu, sehingga orang kita berduyun-duyun pergi ke Makkah.

Manfaat berikutnya, bagi orang yang tidak mampu pergi ke makkah, maka tiap-tiap suku di Minangkabau di buat surau. Maka bertebaranlah surau di alam minangkabau waktu itu. Dalam ceramahnya Buya Zulhamdi mengatakan,

“Waktu kami pai samo buya ado beberapa jamaah surau, menemui rajo pagaruyung Daulat Taufik Thaib. Waktu itu dikali-kalilah berapa jumlah nagari di Minangkabau dulu, berapa pula jumlah suku tiap nagari, dan tiap suku itu terbagi pula sekian. Kesimpulannya dulu di Minangkabau ko ado 2400 surau.cubo bayangkan 24000 surau. Setiap surau sudah dipastikan ada satu orang alim, yang pandai menganjarkan cara sembahyang, cara 
berwudhu, mengajarkan mangaji al qur'an, mengajarkan Feqah atau Fiqih bahasa kini nya. Mengajarkan tauhid. Kalau untuk ukuran zaman kini, dia sudah ulama atau sudah ustadz. Jadi dulu ada 24000 surau sekaligus 24000 ulama di alam Minangkabau.itu hasil dari perang paderi."

Tali tigo sapilin, tungku tigo sajarangan urang nan tigo jinih, niniak mamak, alim ulama, cadiak pandai, berlomba-lomba mendirikan surau.

Tabel 1. Analisis Sosial

\begin{tabular}{|c|c|}
\hline Analisis Sosial & $\begin{array}{c}\text { Adat Basandi Syarak Syarak Basandi Kitabullah: Ceramah } \\
\text { Ustadz Zulhamdi Lc MA di Youtube }\end{array}$ \\
\hline Masyarakat & $\begin{array}{l}\text { Ceramah ustadz Zulhamdi dilaksanakan di Masjid Buya } \\
\text { Gusrizal di Kota Bukittinggi, pada masyarakat suku bangsa } \\
\text { Minangkabau. Dengan menggunakan bahasa daerah yang } \\
\text { bercampur dengan bahasa nasional. }\end{array}$ \\
\hline Kato Pasambahan & $\begin{array}{l}\text { Kato pasambahan merupakan, kata budaya, sebagai tokoh } \\
\text { ulama yang faham adat-istiadat Minangkabau. }\end{array}$ \\
\hline Status Sosial & $\begin{array}{l}\text { Ustadz Zulhamdi Lc, MA Merupakan Ketua MUI Kota } \\
\text { Padang Panjang. Merupakan Alumni Dari MAN Koto Baru, } \\
\text { Padang Panjang. }\end{array}$ \\
\hline Isi Ceramah & $\begin{array}{l}\text { Dalam pesan ceramah yang disampaikan oleh Ustadz } \\
\text { Zulhamdi Lc,MA menggunakan bahasa daerah Minangkabau. } \\
\text { Ceramah ini disampaikan kepada jama'ah dalam lingkup } \\
\text { masyarakat Minangkabau, dan pembahasan dalam konteks } \\
\text { masyarakat dan adat di Minangkabau. Artinya, ceramah ini } \\
\text { ditujukan kepada suatu kelompok masyarakat yang khusus } \\
\text { dalam sistem sosial yang menganut sistem matrilineal, yang } \\
\text { menganut falsafah hidup masyarakat adat Basandi syarak, } \\
\text { syarak basandi kitabullah. } \\
\text { Berbagai permasalahan kompleks yang terjadi seputar } \\
\text { Minangkabau, disampaikan dalam bahasa tutur kato } \\
\text { pasambahan. Memperlihatkan bahwa sosok Ustadz Zulhamdi } \\
\text { Lc, MA adalah orang yang memiliki faham adat. } \\
\text { membicarakan seputarmasyarakat Minangkabau. }\end{array}$ \\
\hline
\end{tabular}

Sumber: Analisis Penulis, 2020

\section{Teks}

Van Dijk melihat suatu teks terdiri atas beberapa struktur/tingkatan yang masing-masing bagian mendukung. Ia membaginya kedalam tiga tingkatan. Pertama, struktur makro, merupakan makna global/umum dari suatu teks yang dapat diamati dengan melihat topik atau tema yang dikedepankan dalam suatu berita. Kedua, superstruktur, merupakan struktur wacana yang berhubungan dengan kerangka suatu teks, bagaimana bagian-bagian teks tersusun ke dalam berita secara utuh. Ketiga, struktur mikro adalah makna wacana yang dapat diamati dari 
bagian kecil dari suatu teks yakni kata, kalimat, proposisi, anak kalimat, parafrase, dan gambar. ${ }^{17}$ Untuk melakukan sebuah kajian analisis wacana terhadap ceramah Ustadz Zulhamdi Lc, MA di Youtube perlu ditinjau dari produksi suatu teks, dapat dilihat dari beberapa struktur/tingkatan yang masing-masing bagian mendukung pemaknaan terhadap teks.

\section{Struktur Makro}

Struktur makro adalah makna secara global atau secara umum dari suatu teks yang bisa diamati dengan cara melihat topik maupun tema yang dikemukakan dalam suatu cerita. kemampuan menarik perhatian konsumumen terutama produk yang iklannya populer atau sangat dikenal masyarakat. Hal ini tentu menyediakan daya jual. ${ }^{18}$ Tema pada ceramah yang dibawakan oleh Ustadz Zulhamdi Lc MA ini adalah Adat Bandi syarak, syarak basandi Kitabullah, syarak mangato, adat mamakai. Kita untuk menginggat kembali bahwa Negeri Minangkabau adalah Negerinya para ulama. Negeri ini melahirkan banyak para ulama yang telah mengislamkan beberapa Kerajaan di Asia Tenggara. Mengingat sejarah Paderi dan meluruskannya yang telah memberikan banyak manfaat bagi tatanan hidup masyarakat di Minangkabau.

Tabel 2. Struktur Makro Ceramah Ustadz Zulhamdi, Lc, MA

\begin{tabular}{lll}
\hline Struktur Makro & Tema & Adat Basandi Syarak, syarak basandi \\
& Kitabullah, syarak mangato adat \\
& mamakai, sebagai landasan hidup \\
& masyarakat Minangkabau. \\
& Membicarakan seputar permasalahan \\
Topik & masyarakat di Minangkabau, mulai dari \\
& konteks sejarah yaitu Dakwah ulama, \\
& dan pergerakan islam. Permasalahan \\
& saat ini, dan solusi yang ditawarkan \\
& untuk menghadapi masa depan \\
& Minangkabau. \\
\hline
\end{tabular}

Sumber: Analisis Penulis, 2020

17 Alex Sobur, Analisis Isi Teks Media: Suatu Pengantar Untuk Analisis Wacana, Analisis Semiotik dan Analisis Framing, (Bandung: PT Remaja Rosdakarya, 2004), hlm. 75-84

${ }^{18}$ Morissan, Periklanan Komunikasi Pemasaran Terpadu, (Jakarta : Kencana, 2010) hlm. 17 


\section{Superstruktur}

Superstruktur yaitu melihat bagaimana bagian dan urutan dalam sebuah wacana dalam hal ini ceramah di skemakan dalam sebuah teks lisan.

Tabel 3. Tabel Superstruktur

\begin{tabular}{|c|c|c|}
\hline Skematik & Pembukaan & $\begin{array}{l}\text { Diawali dengan pembukaan menggunakan kato } \\
\text { pasambahan. } \\
\text { Diisi dengan beberapa poin kajian : } \\
\text { 1. Sejarah } \\
\text { 1. Sejarah Islam Di Minangkabau } \\
\text { a. Minangkabau Negerinya Para ulama } \\
\text { b. Kedatangan Islam Di Minangkabau } \\
\text { c. Gerakan Paderi Di Minangkabau } \\
\text { d. Kekuasaan Di Minangkabau } \\
\text { e. Manfaat Gerakan Paderi } \\
\text { f. Sejarah Pendidikan Di Minangkabau } \\
\text { g. Tokoh Nasional dari Minangkabau } \\
\text { Minangkabau saat Ini } \\
\text { a. Maksiat banyak di Minangkabau } \\
\text { b. LGBT, Narkoba, masalah rumah tangga dan } \\
\text { perceraian } \\
\text { c. Surau-surau Sudah Mulai sepi dan ditinggalkan } \\
\text { 3. Persiapan Untuk Minangkabau masa Depan } \\
\text { a. Ajakan menjaga Syarak mangato adat mamakai } \\
\text { b. Mengajak seluruh kita harus peduli dengan } \\
\text { kondisi masyarakat } \\
\text { c. dakwah kita harus melibatkan banyak unsur } \\
\text { d. kita perlu melahirkan calon-calon para ulama } \\
\text { Kesimpulan dalam pengajian, harapan ustadz Zulhamdi } \\
\text { Lc MA serta ditutup dengan kato pepatah adat }\end{array}$ \\
\hline
\end{tabular}

Sumber: Analisis Penulis, 2020

\section{Struktur Mikro}

Struktur mikro merupakan makna lokal dari suatu wacana yang dapat diamati dari bagian kecil dari suatu teks misalnya, kata, kalimat, proporsi, anak kalimat, maupun gambar.

Tabel 4. Struktur Mikro Pada Ceramah Ustadz

\begin{tabular}{cl}
\hline Semantik Latar & Ustadz Zulhamdi dipercaya mampu menerangkan persoalan \\
& agama dan adat karena latar belakang pendidikan agama dan \\
& gelar adat "Malin mudo" yang ia peroleh. \\
& wawasan yang luas membuat ustadz zulhamdi mampu dengan \\
& mudah menerangkan secara rinci tentang persoalan yang ada di \\
& Minangkabau, di mulai dari sejarah, munculnya gerakan islam \\
& Paderi, dan manfaat dari gerakan islam itu sendiri terhadap \\
& tatanan masyarakat Minangkabau. Ia juga menawarkan
\end{tabular}


beberapa solusi dan harapannya untuk masyarakat Minangkabau di Masa yang akan datang.

Maksud Ustadz Zulhamdi mengatakan "Betapa hebatnya Minangkabau Dahulu, Betapa banyaknya pesantren dulu, betapa banyaknya surau dulu, betapa banyaknya tokoh-tokoh kemerdekaan dulu yang lahir dari negeri kita. Bahkan di Bidang Tafsir tidak ada daerah yang bisa menandingi kita, banyak nya ulama yang menulis tafsir. Tafsir yang pertama ditulis lengkap oleh Prof Mahmud Yunus dari Sungayang, Batusangkar. Tafsir al Furqan ditulis oleh Zainuddin Hamidi, orang Payakumbuh. Tafsir Al Qur'anul Kariim dikarang oleh Mahmud yunus, tafisr Al Azhar dikarang oleh Buya Hamka. Tafsir Rahmat di karang oleh Umar Bakri, orang padang panjang."

Memiliki maksud untuk merefleksi masyarakat agar mau kembali kepada tataran hidup masa lalu yang sesuai dengan adat dan ajaran Islam, dalam falsafah hidup adat basandi syarak, syarak basandi Kitabullah. Sebagai jawaban terhadap persoalan saat in seperti yang dikatakan,

Pra Ustadz Zulhamdi mengatakan, Nagari kita sudah Anggapan berpengalaman, ulama-ulama kita sudah ada. Di datangkan ustadz dari luar, dibahas masalah khilafiyah, di bahas masalahmasalah yang untuk orang Minang tidak perlu di bahas lagi, sudah basi. Tapi di hidupkan kembali. Ini yang kita khawatirkan. Itulah kalau ceramah itu jalan sendiri-sendiri. Mendahulukan oraganisasi masing-masing, paham sendirisendiri.

Nominalisasi Terdapat perbedaan yang signifikan antara keberadaan surausekolah agama-ulama di zaman setelah gerakan Paderi di Minangkabau, dengan zaman sekarang.

"Minangkabau yang saat dulu begitu harum dengan para ulama, tapi ternyata hari ini seperti yang sama sama kita saksikan. Dulu Penduduk 1 juta 500, pesantren agama 1100. Kini penduduk Minangkabau 5 Juta, pesantren yang tersisa 240. Yang 240 itupun sudah bercampur."

Sintaksis Bentuk Dalam ceramah ini bersifat Induktif, yaitu diawali dengan Kalimat keterangan-keterangan dan penjelasan, ditutup dengan intisari dari ceramah. Yaitu upaya mengajak kepada tataran hidup masyarakat Minangkabau.

Koherensi Ulama dahulu ketika dia beda pendapat, berlainan mazhabnya disampaikan di pesantrennya, di sekolahnya pada orang-orang yang terdidik. Kini orang berbicara khilafiyah diatas mimbar, ini yang jadi masalah disampaikan lepas begitu saja diatas mimbar, yang mendengarnya orang-orang lepas begitu saja, mulai orang terdidik, sampai orang awam, sampai orang yang baru taubat, akhirnya sampai di luar semakin liar, semakin terjadi perpecahan. 
Kata ganti Ustadz Zulhamdi nama-nama para Tokoh-tokoh agama atau ulama Minangkabau masa lalu. Dan menyebut para tokoh masyarakat, dengan tungku tigo sajarangan. Niniak mamak, Alim ulama, dan cadiak pandai.

Stilistik Leksikon Bagaimana kata-kata dikemas dengan tampilan yang sesuai dengan fakta yang sebenarnya. Ustadz zulhamdi lebih memilih bahasa cenderung

Retoris Grafis Pada grafis ini menunjukan bahwa suara yang lantang, dan perasaan Ustadz Zulhamdi saat menceritaan masa lalu Minangkabau kabau dengan semangat, dan penuh decak kagum, namun perasaan itu berubah saat ustadz zulhamdi melihat dan menceritakan kondisi sekarang dengan keprihatinan.

Sumber: Analisis Penulis, 2020

\section{Kognisi Sosial}

Analsis wacana tidak hanya membatasi perhatiannya pada struktur teks, tetapi juga bagaimana suatu teks di produksi. Van Dijk menawarkan suatu analisis yang disebut sebagai kognisi sosial. Dalam kerangka analisis wacana Van Dijk perlu ada penelitian mengenai kognisi sosial yaitu kesadaran mental sang Da'i yang menyampaikan ceramah tersebut. Hal terebut dapat dilakukan dengan analisis latar belakang pendidikan, pengalaman, dan lingkungan, kerangka kognisi ini perlu untuk menjadi kerangka analisis yang tidak terpisahkan untuk memahami isi ceramah.

Pendekatan kognisi didasarkan pada pada asumsi bahwa ceramah tersebut mempunyai makna, tetapi makna diberikan oleh sang Ustadz yang memakai bahasa atau proses kesadaran mental dari Ustadz Zulhamdi Lc, MA. Oleh karena itu dibutuhkan suatu penelitian atas representasi kognisi dan strategi sang Ustadz dalam menyampaikan ceramah. Hal tersebut didasari oleh kesadaran, pengetahuan, prasangka, lingkungan, dan pengalaman sang Ustadz. Adapun riwayat pendidikan Ustadz Zulhamdi di bidang agama Islam, diantaranya SMP di MTI Canduang, Kabupaten Agam. MAN Koto Baru Padang Panjang. Selanjutnya Ustadz Zulhamdi melanjutkan Pendikan di Universitas Madinah pada jurusan Hadits dan meraih gelar Lc. Sedangkan Gelar MA ia peroleh dalam bidang Tafsir di UIN Imam Bonjol Padang.

Saat ini Ustadz Zulhamdi Lc, MA menjabat sebagai Ketua MUI Kota Padang Panjang, masa 2016-2020. Selain itu sebagai ulama Sumatera Barat yang hanif, Ustadz Zulhamdi sangat komitmen untuk mempertahankan kehidupan yang sesuai dengan falsafah hidup adat basandi syarak, syarak basandi kitabullah dengan metode ceramah agama di surau-surau. Dari kognisi sosial Ustadz Zulhamdi yang selalu ditempa dengan ilmu agama dan budaya Mianngkabau, maka falsafah adat basandi syarak basandi Kitabullah diyakininya memiliki pengaruh yang besar dalam kehidupan masyarakat terutama dalam mengatasi persoalan kontemporer. 


\section{KESIMPULAN}

Berdasarkan hasil analisis wacana Teun A. Van Dijk terhadap ceramah Ustadz Zulhamdi Lc, MA tentang Adat Basandi Syarak Syarak Basandi Kitabullah di Youtube, ditemukan bahwa wacana yang dilihat, (1)teks yaitu Struktur Makro Tema pada video ceramah agama ini adalah Syarak Mangato Adat Mamakai, mengajak jama'ah untuk menginggat sejarah perkembangan islam di Minangkabau yang melahirkan sebuah landasan hidup adat basandi syarak, syarak basandi Kitabullah. Supersturuk dibuka melalui refleksi tentang sejarah kejayaan islam di Minangkabau yang dikenal sebagai negerinya para Ulama, menjelaskan peran gerakan paderi dan manfaat gerakannya bagi masyarakat Minangkabau, dan ditutup dengan pesan untuk kembali kepada tataran kehidupan yang sesuai dengan falsafah adat Minangkabau yaitu adat basandi syarak, syarak basandi kitabullah. Struktur mikro yaitu angka-angka yang membandingkan bahwa Minangkabau zaman dahulu jauh lebih baik daripada Minangkabau saat ini. (2) kognisi ideology adat basandi syarak, syarak basandi kitabullah yaitu ideologi konservatif. (3) Konteks Sosial melihatkan Bahwa Ustadz Zulhamdi dalam ceramahnya yang berjudul adat basandi syarak, syarak basandi Kitabullah merupakan ideologi konservatif, yaitu upaya mempertahankan atau melestarikan tradisi, sekaligus membatasi perubahan-perubahan. Perubahan yang dimaksud disini bisa berasal dari perubahan globalisasi, teknologi informasi, maupun perubahan perilaku atau gaya hidup yang tidak sesuai dengan nilai dan norma di masyarakat.

Ustadz Zulhamdi Lc, MA sebagai ulama Sumatera Barat sangat komitmen untuk mempertahankan kehidupan yang sesuai dengan falsafah hidup adat basandi syarak, syarak basandi kitabullah dengan metode ceramah agama. Falsafah adat basandi syarak basandi Kitabullah memiliki pengaruh yang besar dalam kehidupan masyarakat terutama dalam mengatasi persoalan kontemporer. Ceramah Ustadz Zulhamdi Lc MA berupaya mengajak jama'ah untuk mempertahankan dan kembali kepada tataran hidup yang telah lama di anut oleh masyarakat di Minangkabau sebagai warisan dari gerakan Islam Paderi di Minangkabau, dapat disimpulkan bahwa Ustadz Zulhamdi, Lc MA memiliki faham konservatif, karena latar belakang Pendidikan agama yang ditempuh serta budaya masyarakat di Minangkabau yang kental dengan adat istiadat. Dalam Kamus Dictionary.com, Konservatif adalah upaya mempertahankan atau melestarikan tradisi lama (kuno) sekaligus membatasi perubahan-perubahan. Perubahan yang dimaksud disini adalah berasal dari perubahan globalisasi, teknologi informasi, maupun perubahan perilaku atau gaya hidup yang bertentangan dengan standar kepatutan nilai, norma adat istiadat dan budaya setempat. 


\section{DAFTAR RUJUKAN}

Abidin, H. Mas'oed, Tiga Sepilin: Suluah Bendang Dalam Nagari. Yogyakarta: Gre Publishing, 2016.

Chaniago, Putra, "Representase Pendidikan karakter Dalam Film Surau dan Silek (Analisis Semiotika Ferdinand De Saussure)", Journal Of Islamic Education Policy, Vol. 4. No. 2 JuliDesember 2019.

Deddy Mulyana, Kajian Wacana: Teori, Metode Aplikasi, dan Prinsip-Prinsip Anlisis Wacana, Yogyakarta: Tiara Wacana, 2005.

Dobbin, Cristine, Gejolak Ekonomi, Kebangkitan Islam dan Gerakan Paderi Minangkabau. Depok: Komunitas Bambu, 2008.

Elvinaro Ardianto dkk., Komunikasi Massa: Suatu Pengantar, Bandung: Simbiosa Rekatama Media, 2009.

Eriyanto, Analisis Wacana : pengantar analisis teks Media, Yogyakarta: PT LKiS Printing cemerlang, 2011.

Fiske, John, Introduction to Communication Studies, London and New York : Routledge, 1999.

F, Simon, Kebudayaan dan Waktu Senggang. Yogyakarta: Jalasutra, 2006.

Hati, Putri Citra, "Dakwah Pada Masyarakat Minangkabau : studi kasus kaum paderi”, Islamic Communication Journal, Vol. 3, No. 1, Januari-Juni 2018.

Koentjaraningrat, Pengantar Ilmu Antropologi, Jakarta: Rineka Cipta, 2009.

Mulyana, Kajian Wacana: Teori, Metode E Aplikasi Prinsip-prinsip Analisis Wacana, Yogyakarta: Penerbit Tiara Wacana, 2005.

Moleong, Lexy J, Metodologi Penelitian Kualitatif, Bandung: Remadja Rosdakarya, 2007.

Rachmat Afandi, Makna Filosofis dalam pepatah Minangkabau Adat Basandi Syara' syara' basandi Kitabullah : analisis semiotika Ferdinan De Saussure, Skripsi : Fakultas Dakwah UIN Sunan kalijaga, 2017.

Safwa Rozi, “Negosiasi Islam Kultur dalam Gerakan Paderi Rao di Sumatera Tengah 1820-1833”, Kalam : Jurnal Studi Agama dan Pemikiran Islam, Vol. 6, No 1. Juni, 2012.

Setiyowati, Ernaning, "Pengaruh budaya dan nilai islam: terbentuknya arsitektur vernakular minangkabau", El-Harakah, Vol. 12. No. 3. Tahun 2010.

Morissan, Periklana Komunikasi Pemasaran Terpadu, Jakarta : Kencana.

Sarbini, Ahmad, "Model Dakwah Berbasis Budaya Lokal Di Jawa Barat”, Jurnal Ilmu Dakwah, Vol. 5. No. 17. Januari-Juni 2011. 
Sobur, Alex. Analisis Isi Teks Media: Suatu Pengantar Untuk Analisis Wacana, Analisis Semiotik dan Analisis Framing, Bandung: PT Remaja Rosdakarya, 2004.

Syamsidar, B.A. Arsitektur Tradisional Daerah Sumatra Barat. Jakarta: Departemen Pendidikan dan Kebudayaan, 1991.

Syam, Nur, "Paradigma dan Teori Ilmu Dakwah : Perspektif Sosiologis" Jurnal Ilmiah Syiar, Vol. 20, No. 01, Januari-Juni 2020.

Tisna, “Tingginya Angka Perceraian Di Sumatera Barat," Metro Padang, 7 September 2020 https:// www.metropadang.com/tingginya-angka-perceraian-di-sumatera-barat/

Yanti, Ni Putu Dewi Eka dan Ida Bagus Putrayasa, I Wayan Artika, "Analisis Wacana Kritis Teun Van Dijk Pada Teks Pidato Klaim Kemenangan Pilpres 2019" jurnal Ilmiah Pendidikan dan Pembelajaran, Vol. 3, No. 3, Oktober 2019.

Yusfita, Rizka Yesri Yusfita, "Populasi LGBT Terbanyak ada di Sumatera Barat, Penyebabnya salah satunya keluarga," Warta Kota Live.com, 7 Mei 2019 https:// wartakota.tribunnews.com/2019/05/07/populasi-lgbt-terbanyak-ada-disumatera-barat-penyebabnya-salah-satunya-karena-keluarga 